Article

\title{
Corporate real estate management and bank profitability
}

\author{
Kenneth A. Donkor-Hyiaman ${ }^{1 *}$, Esther Terkper ${ }^{2}$, Eric P. Tudzi ${ }^{3}$, De-Graft Owusu-Manu ${ }^{4}$, and \\ Benjamin Ajabuin ${ }^{5}$ \\ 1 Kwame Nkrumah University of Science and Technology, Ghana; kwakuhyiaman2@gmail.com \\ 2 Volta River Authority; e.awusi@gmail.com \\ 3 Kwame Nkrumah University of Science and Technology, Ghana; erictudzi@gmail.com \\ 4 Kwame Nkrumah University of Science and Technology, Ghana, d.owusumanu@gmail.com \\ 5 Kwame Nkrumah University of Science and Technology, Ghana; benajabuin@gmail.com \\ * Correspondence: kwakuhyiaman2@gmail.com; Tel.: +233-508-043-011 (K.A.D.H.)
}

Received: 18 April 2021; Accepted: 8 August 2021; Published: 17 September

\begin{abstract}
Acquiring property for any business is capital intensive and for that matter, strategically managing such assets is considered equally important. This paper provides an analysis of the valueadding attributes of corporate real estate management (CREM) and bank performance in Ghana. The multiple regression method was applied to a cross-section of both primary and secondary data sourced from 25 commercial banks in Ghana. The study shows that the banks identify with the valueadding attributes of corporate real estate asset management even though there are variations in the level of importance to individual banks. These variations are attributable to the unique mandates of the banks. Further analysis shows that CREM has significantly positive impacts on bank profitability by strategies that help to increase innovations, increase productivity, and promote marketing and sales. The finding suggests that optimizing these CREM strategies could help increase bank profits.
\end{abstract}

Keywords: Corporate Real Estate; Corporate Real Estate Management; Corporate Real Estate Strategies; Bank Performance; Value Addition; Ghana.

JEL codes: G21, G32, R30, R33

\section{Introduction}

Most corporate entities require some form of real property to perform their core functions, which makes the management of all such properties equally important (Ijasan, 2013). Corporate real estate (CRE) is broadly defined as the real property held or used by a business or organization for its operational purposes (Liang \& Chen, 2011). CRE adds value to the organization (Musa \& AhmadBaharum, 2012), and appropriately managing an organization's real estate can give it a competitive advantage (Appel-Meulenbroek et al., 2010).

Corporate real estate management (CREM) can be defined as the management of real estate by companies or organizations whose core business is not real estate business (Lindholm et al., 2006). It is a new area within the real estate and business community (Omar \& Heywood, 2014). CREM aims to ensure that the corporate strategies align with corporate real estate strategy which in turn, helps the company's performance to improve (Haynes, 2012; Sulaiman et al., 2015). CREM needs to have major effects on an organization's ability to compete in the sector by utilizing space they own effectively (Hartmann et al., 2009). Appel-Meulenbroek et al. (2010), further adds that the key focus of CREM should be to contribute to the brand of the core business of the organization by aligning real estate assets. There is therefore the need for organizations to redirect their focus toward the strategic perspective of CRE as an important tool to enhance the performance of businesses towards achieving their core objectives. 
However, very little attention is paid to the role CREM plays in adding value to a firm, by supporting the core mandate of the company strategically (Lindholm \& Levainen, 2006). In most circumstances, CRE performance is normally measured in terms of the contribution of CRE teams who use real estate to achieve organizational goals instead of the performance of real estate (Jordan et al., 2009). Further, CRE is still viewed by both corporate real estate and general managers as a cost of production that should be minimized rather than a strategic asset for maximizing shareholders' wealth (Lindholm et al., 2006; Lindholm \& Leväinen, 2006; Boakye-Agyeman \& Bugri, 2019). Varcoe (2010) argues that the measurement of CRE issues is property-oriented instead of from the business perspective. This statement reinforces the view that most businesses turn to concentrate on physical assets, such as the expense and inventory of CRE, rather than on business-oriented efficiency and the potential of CRE to increase shareholders' worth.

According to Haynes \& Nunnington (2010), the alignment of corporate strategy with the CREM strategy to add value and enhance organizational performance is an important subject of research. This is because CRE, when strategically positioned, can increase shareholder's value by; increasing the value of assets; promoting marketing and sales; increasing innovation; increasing employee satisfaction; increasing productivity; increasing flexibility; and reducing costs. This would eventually result from inefficient usage of CRE, strong workplace loyalty, better performance of staff, enhanced efficiency, and a high degree of corporate market share (Lindholm \& Leväinen, 2006). Earlier studies suggest that situating business strategy within the context of asset management, facilities management, and property management is a means of achieving the primary goal of corporations to maximize wealth (see Sarosoja et al., 2004). Indeed, aligning CRE goals and priorities with the market, constant portfolio review, including scale, expense, capacity, retention, and profitability, value is generated with optimized shareholders' wealth (Langford \& Haynes, 2015).

Nevertheless, it is quite evident in Africa that CREM is yet to gain ground in the corporate world. This is because initial queries to check the need to undertake this research showed that corporate real estate decisions may not necessarily be taken at the executive level in most firms. The situation in Ghana is worrying as CRE divisions lack consistent strategic governance directives, sufficient organizational capacity, and appropriate supporting frameworks for strategic CRE management activities (Boakye-Agyeman \& Bugri, 2019). CRE managers are not considered to be part and parcel of the strategic development process and hence CRE managers remain 'taskmasters' instead of business strategists. CRE is most often neglected because RE decisions contain a high degree of uncertainties (Krumm \& de Vries, 2003). However, they failed to recognize that CRE can be the tool for balancing risks in financial decisions. Though it is naturally difficult to prove and quantify the value-adding attributes of CRE to a company's performance, it can significantly improve wealth when CREM is strategically positioned in line with organizations' core business, human resources, and ICT management (Lindholm \& Nenonen, 2006). As such, many firms in Ghana seem to underutilize the real estate they own and operate from. Haynes (2012) developed a model to test the alignment of corporate strategies to real estate strategies. The model shows that only when optimum alignment is achieved, can the CRE strategy deliver added value and enhanced organizational performance.

This paper tests the model developed by Haynes (2012) to ascertain its validity in the African context, Ghana to be precise, by examining the value-adding attributes of CREM to bank performance. The paper has five sections. Following this section is section two which provides a review of the extant literature on CREM and the determinants of bank performance. Section three discusses the research data and methodology while section four presents the initial assessment of the data. Section five discusses the results and concludes the study in section six.

\section{Literature Review on Corporate Real Estate Management and Bank Performance}

\subsection{Corporate Real Estate Management: An Empirical Review}

There is evidence of advancement in CREM (Haynes, 2012). Just as other strategic management disciplines, CREM has over the years developed into a strategic management discipline that deserves 
equal consideration (Gibson \& Luck, 2006 in Haynes, 2012). The major objective of the CREM discipline is to improve the performance of firms by aligning their CRE strategies with the overall corporate strategies (McDonagh \& Nichols, 2009; Jensen et al., 2012; van der Voordt, 2017; Jensen \& van der Voordt, 2020). Krumm (1999) initially identified four perspectives of CREM as general management, asset management, facility management, and cost control of corporate real estate management's strategic focus.

Further study by Krumm et al. (2000) showed that property management functions could be subdivided into: the business focus, the real estate focus, the strategic focus, and the operational focus. In many organizations, CREM practices do not only focus on the traditional property management but also on modern property dynamics in managing many other functions which support the physical workspace, business strategies, etc., and integrate them with technological advancements (Varcoe \& O'Mara, 2011). The historic reputation of considering CRE as an avoidable 'cost of production (Omar \& Heywood 2010), is giving way due to the current environment of increasing corporate governance, regulation, and financial transparency.

Many of the early studies were conducted in US, Europe, and China. Veale (1989) studied executive attitudes towards corporate real estate asset management. He found that CREM was evolving into a recognized management activity, which needed a more formal and systematic approach while retaining its identity as a service function of the overall mission and purpose of an organization. He further mentioned that effective CREM includes a proactive and comprehensive decision-making process, well supported by adequate and timely information and the commitment of upper management (which was found to be quite low). Thus, the focus of CREM is on value-adding to an organization in two economical terms: cost-cutting and profitability growth (Jensen, et al., 2012).

However, Gale \& Case (1989) found that real estate resources were found in lower management in America. Roulac, et al. (2000) showed that the potentials of these professionals who are well-versed in CRE were not fully exploited, and for that matter, the main aim of CREM is not fully appreciated. Veale (1989) noted that despite the value of CRE to the organization, it was seriously undermanaged. Further studies conducted by Scheffer, et al., (2006) with regards to the contribution of CRE to corporate strategy, found that many corporations still lacked an adequate understanding of the effects of CRE decisions on firms' performance. A recent study by Boakye-Agyeman \& Bugri (2019) indicates that the situation in Ghana is not different from the global trend that CRE has not been strategically managed like other corporate assets. This situation indicates the lack of recognition of the valuable real estate can add to a company and hence their under-utilization (Ijasan, 2013; Hartmann et. al., 2009). This is perhaps because the contribution of real estate to value is difficult to quantify (Gadzekpo et al., 2015) especially among organizations that are not primarily in the real estate business.

Even when CREM is deemed necessary, it is ranked lower than financial imperatives (Kenley and Heywood, 2000) and considered too expensive (Liang \& Chen, 2011) by firms. Most companies just want to lease or own a perfect office with good environment and convenient transportation, but not much attention is given to the value CREM can add to the firm (ibid.). Although some firms recognize the three distinct categories of a CRE portfolio, i.e., financial assets, real estate market assets, and operational assets (Ijasan, 2013), a collective management strategy is needed to efficiently maximize their contributions to company profits, which seldomly happens (Varcoe, 2000).

The debate has certainly moved from 'whether or not CREM enhances value' to 'how CREM can enhance it' (Ijasan, 2013; Jesen \& van der Voordt, 2020). Lindholm and Levainen (2006) posited that not much attention is paid to the value-adding the role of CREM by strategically supporting the core business of organizations. Heywood (2011) studied the literature on CREM to appraise theoretical models which tried to create a link between corporate strategy and CREM and found that, the methods of aligning CRE tend to fall into one of two camps: single CRE factor or multivariate alignment models. Heywood (2011) further acknowledged 10 different alignment models which included components ranging from 7 to 15. Later, Haynes (2012) developed the 10 Ps CREM alignment model - people, processes, paradigm, place, procurement, purpose, position, planet, productivity, and performance. CREM integrates, directs, and supports the strategic alignment of an organization's business processes, 
purpose, position, and paradigm with its underlying assets, including people and places through appropriate procurement of its working environment. de Vries et al. (2008) found out that CRE interventions improved organizational performance. Successful strategic implementation of CREM creates opportunities for positive impacts upon the performance and productivity of the organization (Haynes \& Nunnington, 2010). For instance, through performance measurement methods, Langford, and Haynes, (2015) observe that CRE does not only increases utilization and efficiency in the financial industry but also increases productivity, by reducing CRE overheads and organizational attrition rates. In essence, CRE contributes value to the core business, both in the physical and behavioral settings.

It is, therefore, essential for corporations to view real estate as assets that can and should be actively managed to achieve corporate goals and in turn, enhance shareholder values (Miles, et al., 1989). According to Krumm et al. (1998), to continue to provide an added value to the internal clients within an organization, the real estate management departments must be aware of these key elements: their capabilities and resources, the changing needs and authorities within the corporation, the context and markets in which the organization operates and the presence of corporate awareness of products and services available within the staff and service departments. Ijasan, (2013) and Boakye-Agyeman \& Bugri (2019) argues that the contributions of the CRE personnel will be felt and appreciated more as they move upwards on the functional level to the top-level role of a business strategist where their function is to integrate workforce, workplace, and technology trends into overall business strategy.

\subsection{Bank Performance and Corporate Real Estate}

The banking sector remains key for the economies of various countries especially among developing economies like Ghana where the capital market is at nascent stages of development (Matthew \& Laryea, 2012). There have been several interventions seeking the survival and growth of the sector since it is the backbone of the financial system of developing economies. These include but are not limited to various recapitalization regimes (Matthew \& Laryea, 2012), partial liberalization of interest rates, and removal of sectoral credit ceilings (Nkegbe \& Ustarz, 2015). These factors arguably transcend the performance of the banks and the industry.

The success of this business is typically based on the effective utilization and control of certain assets to maximize competitive advantage (Gadzekpo et al., 2015). Among such resources include buildings and other associated landed properties. The performance and profitability profile of banks are influenced by both micro and macroeconomic factors (Yakubu, 2016). Khrawish, (2011) describes the micro factors as internal and company-specific factors that stem from the decisions of management. This includes the allocation of resources and asset management like cooperate real estate. These factors are non-financial statement indicators that affect the cost and revenue of banks (Yakubu, 2016). By using the Economic Value Added (EVA) technique Owusu-Antwi et al. (2015) observe that bankspecific variables such as cost to income ratio, the liquid assets, and the total asset of banks correlates positively with the banks' performance. The assets base of these banks includes buildings and other related landed property. In addition, bank age, size, funds, ownership structure, and listing status have a great effect on their performance (Adusei, 2011). He further posits that the size of the board of directors of a bank has an inverse relationship with the profitability indexes.

The macroeconomic factors on the other hand are external and industry-related determinants that cannot be controlled by banks but have a significant influence on the profitability of banks (Krakah \& Ameyaw, 2010). Yakubu, (2016) posits that the improvement in the profitability of banks, especially among commercial banks is because of the growing number of banks and the increased competitiveness within the banking sector in Ghana. Other factors such as liquidity, market share of loan and operational efficiency have a direct relationship with all performance indicators of banks while non-performing loans, money supply, and gross domestic product have an inverse relationship with profitability indexes including return on equity and return on assets (Nkegbe \& Ustarz, 2015).

Bikker (2010) distinguishes five types of performance indicators - competition, profit, cost, efficiency, and market structure. Various theoretical relationships exist between the several types of 
performance. According to the structure-conduct-performance (SCP) theory, market structure determines competitive conduct and thus profits (Bos, 2004). Within this framework, higher profits result from less competition due to high bank concentration. On the other hand, the efficiency hypothesis postulates that more efficient banks increase their market share by pushing less efficient competitors from the market (Demsets, 1973). Therefore, competitive pressure forces banks to become more efficient (c.f. Hicks, 1935). Banks can become more competitive to increase market share by lowering their prices enabled by excess profits. According to Bikker (2010), the strong relationship among market structure, costs, and profitability justify their predominant use as proxies for competition and efficiency.

In an empirical investigation of the structure, conduct, and performance of commercial banks in Ghana, Nabieu (2013) uses measures of concentration (i.e., Loan-to-deposit ratio and concentration ratio on deposit) to represent market structure, a market share variable to capture the effect of market conduct, and the return on assets (ROA) and return on equity (ROE) to represent the profitability of banks. Profitability indicators, which are of crucial importance to shareholders, customers, and the continuous growth and survival of the whole industry help to measure improvements in financial service delivery (Bikker, 2010). Further, company performance and profitability indexes are key indicators of national growth and employment in the medium term (Nkegbe \& Ustarz, 2015).

\section{Data and Methods}

In the development of knowledge, certain beliefs and assumptions are made at any point in time whether deliberately or not to give an underlying basis for the choice of research design, methodology, data collection, and analysis procedures (Burrell \& Morgan, 1979). In the quest to discover measurable facts about CREM and bank performance, the quantitative methodology, which involves the systematic process of asking and answering scientific questions by making observations, formulating a hypothesis, collecting data, and testing by way of experiments (Cohen, Manion, \& Morrison, 2013) is adopted. This study is structured to explore ways for the collection and analysis of data that will consequently lead to an understanding of how CREM affects bank performance in Ghana.

Ghana is a western African country with a southern coastline at the Gulf of Guinea. Countries with international borders to Ghana are Burkina Faso, Cote d'Ivoire (Ivory Coast), and Togo. With an area of $238,533 \mathrm{~km}^{2}$, the nation is slightly smaller than the UK and has a population of almost 30 million inhabitants (in 2020). Ghana was chosen mainly due to data availability and its financial soundness typifying that of other African countries. For instance, data from the International Monetary Fund shows that the median capital-to-assets in Ghana $(13.11 \%)$ is just $1 \%$ more than the African median (12.11\%) (European Investment Bank, 2018). The report further shows that the median return on assets for banks in Ghana (4.29\%) is about $2 \%$ more than the African median (2.96\%).

Based on data availability, the study relied on cross-sectional and time-series data obtained from 25 banks in Ghana out of the 37 existing commercial banks in 2017. The study adopted a multi-stage probability sampling technique for the selection of the banks because of the data requirements for this study - data on experienced banks with audited financials covering a reasonable period. Multistage sampling entails two or more stages of random sampling based on the hierarchical structure of natural clusters within the population (Sedgwick, 2015). A different type of cluster is randomly sampled at each stage, with the clusters nested within each other at successive stages (ibid.). Two stages were involved in this study as shown in Table 1. In the first stage, we collected financial data on banks from their published audited accounts for the 2006 - 2015 period. This was the period for which balanced data on most of the banks existed. At this stage, 33 out of a total of 37 banks were selected. The second and final stage of sampling involved choosing a random sample of units in the cluster selected at the penultimate stage (ibid.). For this study, this stage involved the selection of banks that had CREM strategies. A total of 25 banks emerged.

Bank performance was measured by a combination of the average return on assets and the average return on shareholders' funds for the period 2006 to 2015. This action was taken because of the strong correlation $(98.6 \%)$ between them. The combined variables are measured over 200 and 
further rescaled to $100 \%$. The value-adding attributes of CRE derived from Haynes (2012) as summarized in Table 2 were then presented to the Managers of the banks for a rating on a 5-point Likert scale. On this scale "1" = least important; "2" = slightly important; "3" = moderately important; "4" = important; " $5 "$ = most important. Other variables affect bank performance. To be able to predict the unique relationships between the value-adding attributes of CRE and bank performance, it is prudent to control for all the other bank performance explanatory variables, which serve as alternative explanatory variables. Therefore, we use the 'increase customer base', 'increase funds/deposits', 'reduce loan defaults', and 'outsourcing of real estate functions' variables as controls.

Table 1. Selection of Banks

\begin{tabular}{cccc}
\hline Level & Description & $\begin{array}{c}\text { Total } \\
\text { Number of } \\
\text { Banks }\end{array}$ & $\begin{array}{c}\text { Number } \\
\text { of Banks }\end{array}$ \\
\hline 1 & Publication of audited financial statement (2006 - 2015) and number & 37 & 33 \\
2 & $\begin{array}{c}\text { of years in operation }(<=8 \text { years }) \\
\text { Availability of CREM strategies }\end{array}$ & 33 & 25 \\
\hline
\end{tabular}

Following previous literature (Haynes, 2012; Roulac et al., 2000), the study used the multiple regression method to examine the relationship between the value-adding attributes of CRE and bank performance. One of the attractions of regression analysis is that it enables the creation of a mathematical model that can be used for predicting or explaining the relationship among variables (at least one independent and one dependent variable) across a broad set of observations (Green, 2010). The following regression model was estimated:

$$
\begin{aligned}
& Y i=\beta 0+\beta 1 X 1 i+\beta 2 X 2 i+\beta 3 X 3 i+\beta 4 X 4 i+\beta 5 X 5 i+\beta 6 X 6 i+ \\
& \beta 7 X 7 i+\beta 8 X 8 i+\beta 9 X 9 i+\beta 10 X 10 i+\beta 11 X 11 i+\varepsilon i
\end{aligned}
$$

Where;

$Y_{i}=$ Dependent Variable (return on total assets and return on shareholders' funds combined);

$\beta_{0}=$ Intercept, $\beta_{1}-\beta_{10}=$ Coefficients of the independent variables; and $X_{1 i}-X_{11 i}$, the independent variables, as presented in Table 2 .

\section{Results}

The study results are presented under four main sub-sections. The first section is on the asset profile of the banks, followed by bank performance and profitability, value adding attributes of CRE, and finally the regression results.

\subsection{Asset Base of the Banks}

Figure 2 shows that on the average, Property, Plant and Equipment (PPE) of banks in Ghana constitute only about $3.19 \%$ of total assets. However, real property and buildings constitutes not less than $63 \%$ of fixed assets across the period of examination. The audited accounts also reveal that, five banks have leasehold assets which add to their CRE but do not have any significant impacts on the average percentage to total assets. It is also observed that PPE/total assets of the sampled banks do not follow any significant trends. On the average, the percentages keep fluctuating across the various banks over the years. These fluctuations may be due to the purchase of equipment, due to their shorter life spans as compared to real estate. Changes in technology may also influence a bank's decision to purchase new equipment so the bank can be up to date with current technology. 
Table 2. Variables and Definitions

\begin{tabular}{|c|c|c|}
\hline Variable & Measure & Code \\
\hline Bank Performance & $\begin{array}{l}\text { Average return on assets and shareholder } \\
\text { funds }\end{array}$ & $Y_{i}$ \\
\hline Reduce cost & & $X_{1 i}$ \\
\hline Increase flexibility & & $X_{2 i}$ \\
\hline Increase employee satisfaction & & $X_{3 i}$ \\
\hline Increase productivity & & $X_{4 i}$ \\
\hline increases innovations & & $X_{5 i}$ \\
\hline Promote marketing and sales variable & o-point Likert scale "1" = least important; & $X_{6 i}$ \\
\hline Increases value of assets & 2 = sligntly important; 3 = moderately & $X_{7 i}$ \\
\hline Increase customer base & Important, 4 =-important, 5 = most & $X_{8 i}$ \\
\hline Increase deposits & & $X_{9 i}$ \\
\hline Reduce loan deposits. & & $X_{10 i}$ \\
\hline & Dummy variable (' 1 ' if bank has an in-house & \\
\hline CREM strategy & $\begin{array}{c}\text { CREM team or ' } 0 \text { ' if outsourcing real estate } \\
\text { functions) }\end{array}$ & $X_{11 i}$ \\
\hline
\end{tabular}

Figure 2. Average Corporate Real Estate/Total Asset and Corporate Real Estate/Fixed Asset Ratios (2006 - 2015) across 25 Banks.

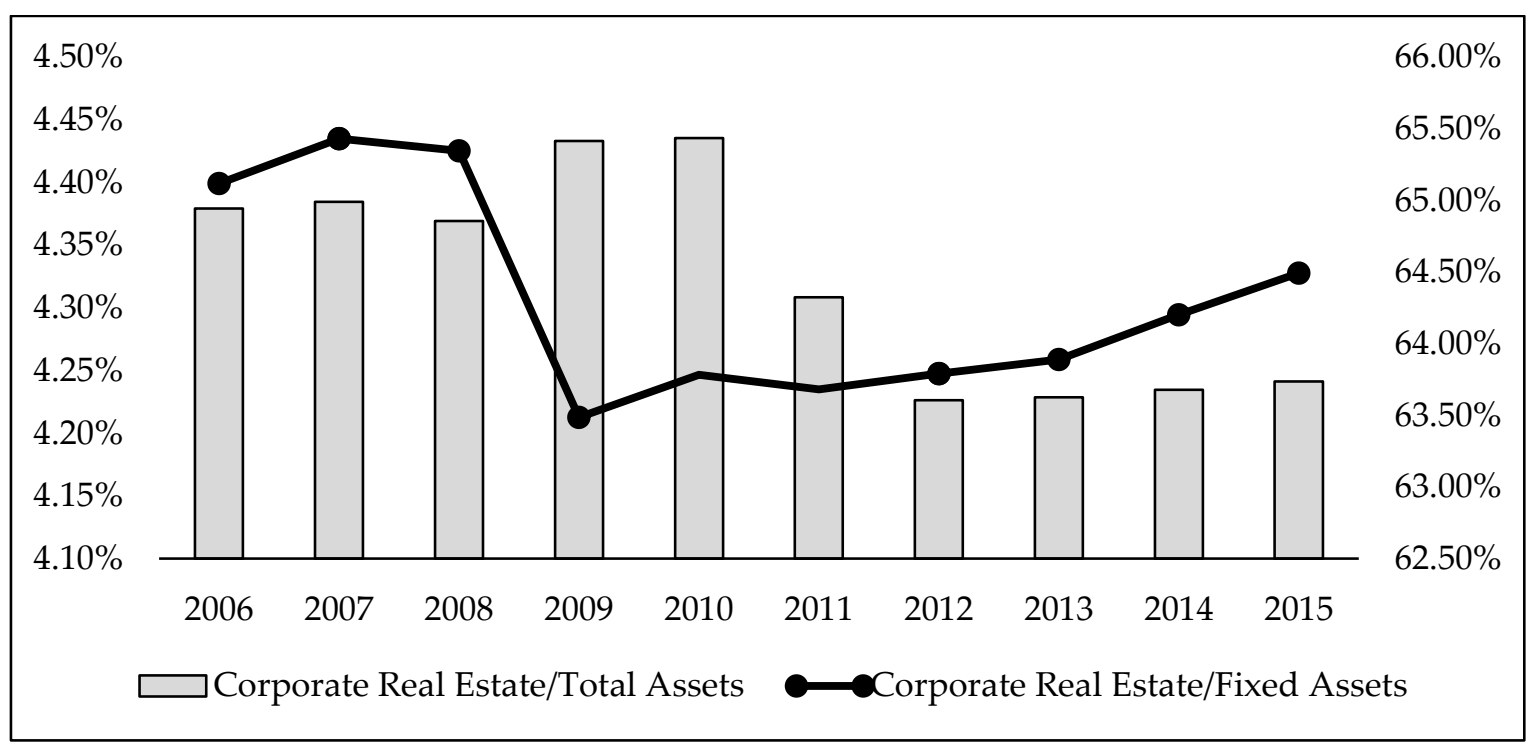

Note: Corporate Real Estate is measured as the sum of property, plant, and equipment (PPE), leasehold property, and investment property.

\subsection{Bank Profitability}

Figure 3 presents the average return on assets and equity (combined) for 29 banks over the 2006 -2015 period. The average return is approximately $13 \%$ with a standard deviation of $3.1 \%$. The low standard deviation indicates that the average return of many banks over the period was similar. The range was however $11 \%$, with the worst performing bank (i.e. First Bank of Nigeria) returning $7.5 \%$ and the best performing bank (i.e. Guarantee Trust Bank) returning 18.6\%. This return data has a 
skewness of -0.28 , which indicates that the data is approximately symmetric ${ }^{1}$. Before that, the next section examines these value adding attributes of CRE independently as rated by the Managers of the selected universal banks.

Figure 3. Average Return on Assets and Equity (Combined) (\%) across Banks

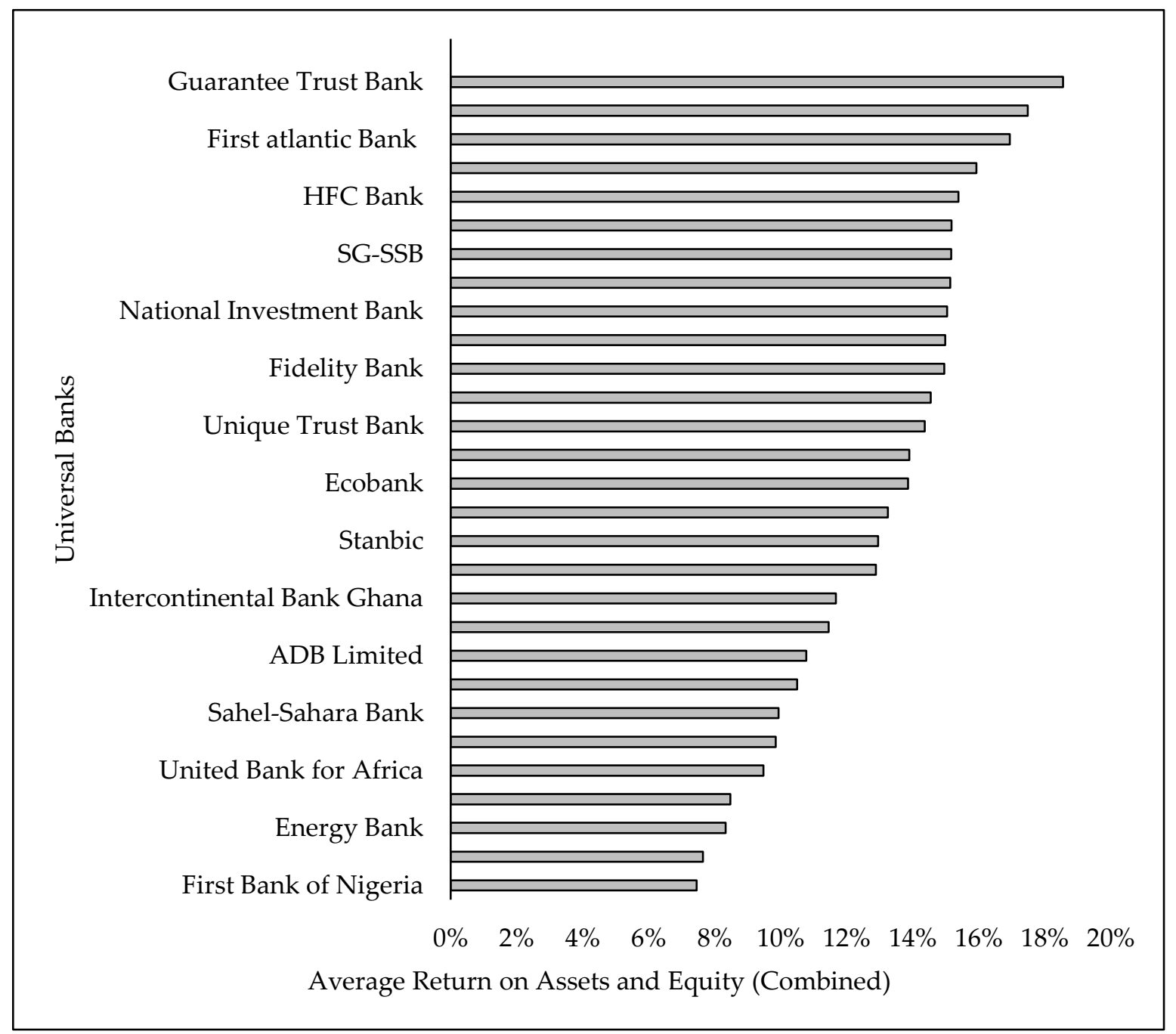

\subsection{Value Adding Attributes of Corporate Real Estate}

Figure 4 presents the averages of the Likert scale results that illustrate the importance of the value adding attributes of CRE to the banks as rated by the respective bank managers. The most important strategy to banks in Ghana is to "reduce cost" (4.80) and the least important is to "promote marketing and sales" (3.80). The rest of the strategies in ascending order of importance are to increase asset values, increase productivity, increase employee satisfaction, increase innovations, and increase flexibility. The next section examines the effect of these value adding attributes of CRE on bank performance.

\footnotetext{
1 Skewness between -0.5 and 0.5 is referred to as approximately symmetric and skewness between -1 and 0.5 is referred to as moderately skewed and then if skewness is less than -1 or greater than 1 , the distribution is highly skewed (Oliveira et al, 2013).
} 
Figure 4. Value Adding Attributes of Corporate Real Estate

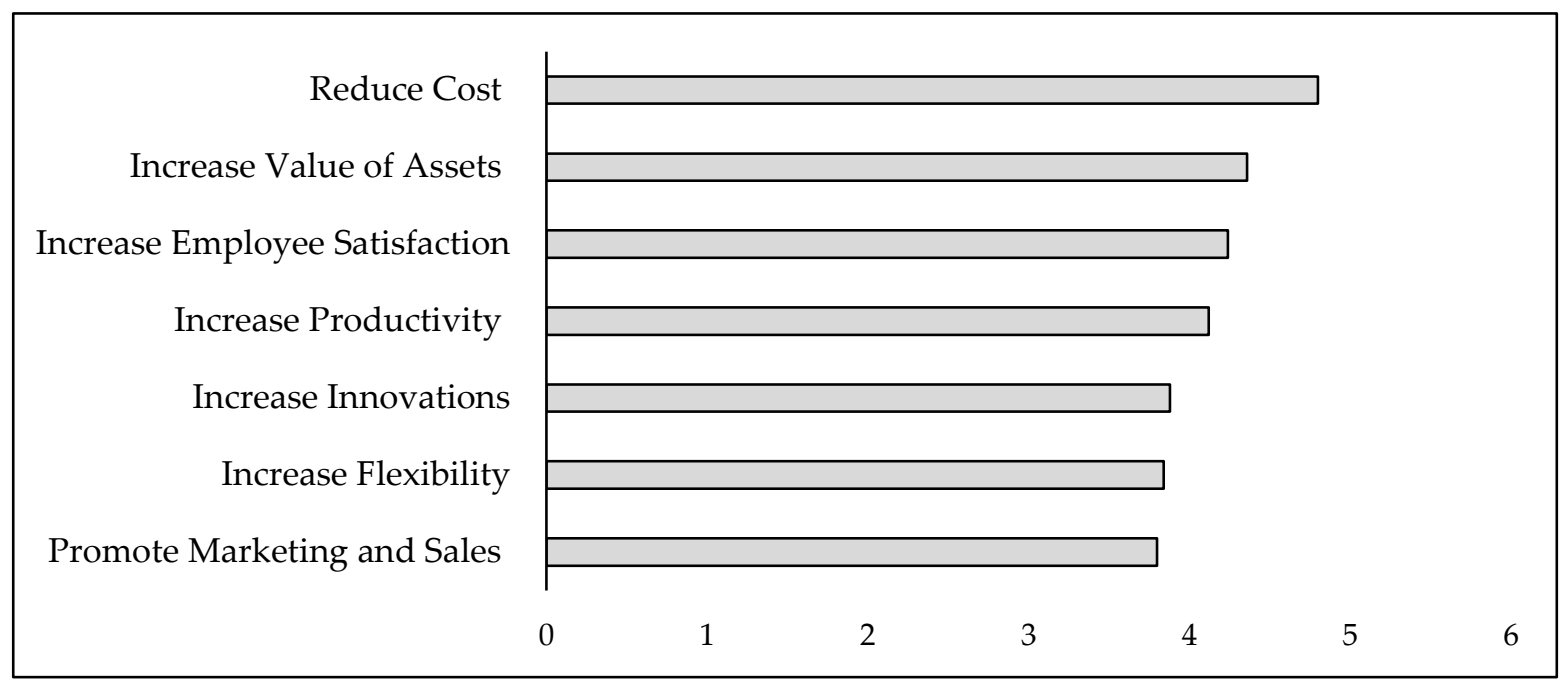

\subsection{Regression Results}

The regression results are presented in Table 3 . The overall model is significant at $5 \%$ significance level. The model explains about $72.77 \%$ of variations in bank performance. This implies that CREM is essential in assessing overall bank profitability in Ghana. This study provides that the 'increase value of assets' and 'increase flexibility' CREM variables are positively associated with the average return on assets and shareholder funds but are statistically insignificant. It can also be observed that the 'promote marketing and sales' variable is positively associated with the average return on assets and shareholder funds, and statistically significant $(10 \%)$. This implies that real estate targeted at promoting marketing in the case of banks can help increase bank performance. Both 'increase innovations' and 'increase productivity' variables have positive associations with the average return on assets and shareholder funds and are statistically significant (5\%). Generally, a reduction in productivity will lower a company's profitability. Real estate and space use can be managed efficiently in such a way that it will boost the profitability of a company. It is important to select good sites to locate banks and be strategic in interior design and infrastructure. It is prudent to give due consideration to these factors because they have rippling effects on the productivity of staff and increase profitability in turn.

\section{Discussion of Results}

Corporate Real Estate (CRE) remains a critical component of any organisational unit. For organisations whose core business are not real estate, CRE is at the centre of promoting employees' satisfaction, motivation, and productivity (Lindholm et al., 2006). CRE provides the enabling environment for employees and organizational processes (Van der Voordt, 2016). Therefore, Oladokun and Aluko (2012) proposed the need for re-engineering so that banks in African countries can fully benefit from the contributions of CRE to successful organizational performance. Theory indicates that the CREM strategies have various impacts on overall corporate performance, but the direction (whether negative or positive coefficient) had not been clearly provided in the literature.

The study revealed that CRE constitutes at least $63 \%$ of the total fixed asset base of the banks under examination over a 10-year period and an average of $3.19 \%$ of the total assets of the banks. This confirms Wudermann's (2012) assertion that CRE forms $10 \%$ or less of a company's total assets. Instructively, the size of CRE to the banks' assets base was generally low. Indeed, a reasonable observation from this finding is that CRE is not a significant component of bank assets in Ghana. This may be attributed to their limited ownership of real estate assets. Further, the activities of banks may 
not necessarily require them owning real estate assets, as compared to the manufacturing sector which may require a plant to run their operations and warehouses to keep their wares.

Table 3. Regression result from cross-sectional data

\begin{tabular}{|c|c|c|}
\hline & Coefficients & Significance \\
\hline \multirow[t]{2}{*}{ Increase Value of Assets } & 0.128 & No \\
\hline & $(0.312)$ & \\
\hline \multirow[t]{2}{*}{ Increase Innovations } & $0.296^{* *}$ & Yes \\
\hline & $(0.004)$ & \\
\hline \multirow[t]{2}{*}{ Promote Marketing and Sales } & $0.177^{*}$ & Yes \\
\hline & $(0.071)$ & \\
\hline \multirow[t]{2}{*}{ Increase Productivity } & $0.424^{* *}$ & Yes \\
\hline & $(0.002)$ & \\
\hline \multirow[t]{2}{*}{ Increase Flexibility } & 0.061 & No \\
\hline & $(0.532)$ & \\
\hline \multirow[t]{2}{*}{ Increase Employee Satisfaction } & 0.092 & No \\
\hline & $(0.353)$ & \\
\hline \multirow[t]{2}{*}{ Reduce Cost } & -0.068 & No \\
\hline & $(0.671)$ & \\
\hline \multirow[t]{2}{*}{ Increase Customer Base } & 0.283 & No \\
\hline & $(0.133)$ & \\
\hline \multirow[t]{2}{*}{ Increase Deposits } & $0.473^{* *}$ & Yes \\
\hline & $(0.014)$ & \\
\hline \multirow[t]{2}{*}{ Reduce Loan Defaults } & -0.343 & No \\
\hline & $(0.101)$ & \\
\hline \multirow[t]{2}{*}{ In-House Management } & 0.261 & No \\
\hline & $(0.162)$ & \\
\hline Significance F & 0.001 & \\
\hline Adjusted R square & $72.8 \%$ & \\
\hline Observations & 25 & \\
\hline
\end{tabular}

Note: ${ }^{*}, * *{ }^{* * *}$ represents significance at $10 \%, 5 \%$, and $1 \%$ levels, respectively.

The results depict a profitability range of $7.5 \%-18.6 \%$ for the banks. A low standard deviation was observed which suggests that the results were evenly distributed around the mean result of $13 \%$. Further, the results suggest that there is greater focus on CRE as tool for reducing cost, increasing asset values, productivity, and employee satisfaction. This is important since corporate real estate and general managers as a cost of production (Lindholm et al., 2006; Lindholm and Leväinen, 2006; BoakyeAgyeman and Bugri, 2019). The underlying message from these results is that CRE is a tool for promoting satisfaction; motivating and stimulating productivity of employees within the organisational unit, which is consistent with Van der Voordt (2016). Strategically, CRE location can be a tool for promoting organisational marketing and sales strategies. This is because the 'promote marketing and sales' variable was found to be significant and positively associated with bank profitability. The results further suggest that real estate and space management when efficiently and effectively carryout can boost the performance of banks. This include but not limited to good site location, good interior design and working environment. The overall goal is to position CRE at the centre of doing business since the organisational functional unit revolves round it.

\section{Conclusion}

This study set out to identify the value adding attributes of real estate in Ghana with a specific application to the banking sector and check their impacts on the performance of the banks studied. In this regard, literature around the thematic area of corporate real estate management which served as 
the theoretical basis for the study was reviewed. Various models were reviewed and that of Haynes (2012) was adopted for the study. Data on CREM strategies was collected from the various banks using a questionnaire. The banks also provided audited financial reports needed for the study. The data gathered were collated and analysed quantitatively.

The study confirms that CREM levels in banking sector of Ghana are low - 3.19\% of their total assets. During the sampling process, some of the banks did not have corporate real estate strategies. It was found that some strategies were being practiced indirectly. This confirms that CREM is probably not considered an important factor in overall corporate performance assessment. This implies among other things that the banking sector may not necessarily see CREM to be a very important factor with regards to bank performance. But the study reveals that even though the percentage of real estate assets owned is low, it does not imply that banks in Ghana are under-performing. It simply means the sector does not necessarily require a lot of real estate assets to increase or enhance their profitability.

The analyses also reveal that various banks in Ghana have adopted all the seven CRE strategies as set out in extant literature. Out of the seven strategies, five of them that seem to affect the profitability of banks in Ghana are increase value of assets; increase innovations; promote marketing and sales; increase productivity; increase flexibility. But statistically, only three of them, namely, increase innovations, increase productivity; and promote marketing and sales are statistically significant. In sum, despite the low rate of CRE among banks in Ghana, it is important to note that CREM has significant impacts on their profitability. Since the goal of the firm is the maximization of the wealth of its shareholders according to the shareholder value theory, banks in Ghana may have to consider the prospects of CREM in the enhancement of profitability. It may be concluded that, if the value adding attributes of CRE are properly strategized, CREM will be a very important factor in enhancing company's profitability.

Author Contributions: Conceptualization, K.A.D.H. and E.T.; methodology, K.A.D.H. and E.T.; software, E.T..; validation, K.A.D.H., E.T., and B.A. and E.P.T.; formal analysis, K.A.D.H. and E.T.; investigation, K.A.D.H., E.T., and B.A.; resources, E.P.T. and B.A.; data curation, E.T.; writing-original draft preparation, K.A.D.H., B.A., and E.P.T.; writing-review and editing, E.P.T.; visualization, B.A.; supervision, E.P.T. and DOM.; project administration, E.T. and DOM. All authors have read and agreed to the published version of the manuscript.

Funding: This research received no external funding.

Acknowledgments: The authors acknowledge all research participants for their time and insights, and the Department of Land Economy, Kwame Nkrumah University of Science and Technology, for facilitating the proofreading of this paper. We also appreciate the anonymous reviewers for their helpful feedback.

Conflicts of Interest: The authors declare no conflict of interest.

\section{References}

Adusei, M. (2011). Board structure and bank performance in Ghana. Journal of Money, Investment and Banking, $19(1), 72-84$.

Gadzekpo, D. A. A., \& Agyeman, N. A. B. Real estate management and value adding in corporate institutions in Ghana. European Journal of Business and Management, 7(17), 36-54.

Appel-Meulenbroek, R., Havermans, D., Janssen, I., \& van Kempen, A. (2010). Corporate branding: an exploration of the influence of CRE. Journal of Corporate Real Estate, 12(1), 47-59

Bikker, J. A. (2010). Measuring performance of banks: an assessment. Journal of Applied Business and Economics, 11(4), 141-159.

Boakye-Agyeman, N. A., \& Bugri, J. T. (2019). Strategic corporate real estate management practice in Ghana. Property Management, 37(3), 432-447.

Bos, J. W. (2004). Does market power affect performance in the Dutch banking market? A comparison of reduced form market structure models. De Economist, 152(4), 491-512.

de Vries, J. C., De Jonge, H., \& Van Der Voordt, T. J. (2008). Impact of real estate interventions on organisational performance. Journal of Corporate Real Estate, 10(3), 208 - 223.

Gale, J., \& Case, F. (1989). A study of corporate real estate resource management. Journal of Real Estate Research, $4(3), 23-34$. 
Hartmann, S., Linneman, P. D., Pfnür, A., \& Siperstein, B. (2009). Realizing the value of corporate real estate management. Wharton Real Estate Review, 13(1), 21.

Haynes, B. P. (2012). Corporate real estate asset management: aligned vision. Journal of Corporate Real Estate, 14(4), 244-254.

Haynes, B., \& Nunnington, N. (2010). Corporate real estate asset management: strategy and implementation. Estates Gazette.

Hicks, J. R. (1935). Annual survey of economic theory: the theory of monopoly. Econometrica: Journal of the Econometric Society, 1-20.

Ijasan, K.C. (2013). Potentials of strategic corporate real estate management: South African perspective. International Journal of Economics, Business and Finance, 1(8), 235 - 248.

Jensen, P. A., \& van der Voordt, T. J. (2020). Typology of value adding FM and CREM interventions. Journal of Corporate Real Estate, 22(3), 197-211.

Jensen, P. A., van der Voordt, T., Coenen, C., von Felten, D., Lindholm, A. L., Nielsen, S. B., \& Pfenninger, M. (2012). In search for the added value of FM: what we know and what we need to learn. Facilities, 30(5/6), 199217.

Jordan, M., McCarty, T., \& Velo, B. (2009). Performance measurement in corporate real estate. Journal of Corporate Real Estate, 11(2), 106-114.

Kenley, R., \& Heywood, C. (2000, September). Corporate real estate management practice: contrasts between financial and service provision priorities in corporate and government organisations. In 16th Annual ARCOM Conference 6-8 September 2000. Glasgow Caledonian University.

Khrawish, H. A. (2011). Determinants of commercial banks performance: Evidence from Jordan. International Research Journal of Finance and Economics, 81(1), 148-159.

Kofi, A., \& Aeron, K. (2010). The Determinants of Bank's Profitability in Ghana, The Case of Merchant Bank Ghana Limited (MBG) and Ghana Commercial Bank (GCB). Unpublished MBA Thesis, Blekinge Institute of Technology.

Krumm, P. J., Dewulf, G., \& De Jonge, H. (1998). Managing key resources and capabilities: pinpointing the added value of corporate real estate management. Facilities, 16 (12/13), 372 - 379.

Krumm, P. J. M. M. (1999). Corporate real estate management in multinational corporations: a comparative analysis of Dutch corporations. Nieuwegein: Arko publishers.

Langford, L., \& Haynes, B. (2015). An investigation into how corporate real estate in the financial services industry can add value through alignment and methods of performance measurement. Journal of Corporate Real Estate, 17(1): 46-62.

Lindholm, A. L., Gibler, K., \& Leväinen, K. (2006). Modeling the value-adding attributes of real estate to the wealth maximization of the firm. Journal of Real Estate Research, 28(4), 445-476.

Lindholm, A. L., \& Leväinen, K. I. (2006). A framework for identifying and measuring value added by corporate real estate. Journal of Corporate Real Estate, 8(1):38-46.

Lindholm, A. L., \& Nenonen, S. (2006). A conceptual framework of CREM performance measurement tools. Journal of Corporate Real Estate, 8(3): 108-119.

Manning, C., \& Roulac, S. E. (2001). Corporate real estate research thought leadership continues to evolve. Journal of Real Estate Research, 22(1/2), 1.

Matthew, N. G., \& Laryea, A. E. (2012). A financial performance comparison of foreign vs local banks in Ghana. International Journal of Business and Social Science, 3(21).

McDonagh, J., \& Nichols, G. (2009). Business strategy and property strategy-how strong is the linkage? Journal of Corporate Real Estate.

Miles, M., Pringle, J. \& Webb, B. (1989). Modelling the corporate real estate decision. Journal of Real Estate Research, $4(3), 47-66$.

Musa, M. F. B., \& a Baharum, Z. A. (2012). Corporate Real Estate (CRE): Public institution of higher learning in Malaysia. Procedia-Social and Behavioral Sciences, 36, 273-279.

Nabieu, G. A. (2013). The structure, conduct and performance of commercial banks in Ghana. European Journal of Business and Innovation Research, 1(4), 34-47.

Nkegbe, P. K., \& Ustarz, Y. (2015). Banks performance in Ghana: Trends and determinants. Ghana Journal of Development Studies, 12(1-2), 33-52.

Oladokun, T. T., \& Aluko, B. T. (2012). Corporate governance and real estate assets management in Nigerian banks. Journal of Corporate Real Estate, 14 (3), 182 - 195.

Omar, A. J., \& Heywood, C. A. (2014). Defining a corporate real estate management's (CREM) brand. Journal of Corporate Real Estate, 16(1), 60-76. 
Owusu-Antwi, G., Mensah, L., Crabbe, M., \& Antwi, J. (2015). Determinants of bank performance in Ghana, the economic value added (EVA) approach. International Journal of Economics and Finance, 7(1), 204-215.

Stephen, R. (2001). Corporate property strategy is integral to corporate business strategy. Journal of Real Estate Research, 22(1-2), 129-152.

Scheffer, J. J., Singer, B. P., \& Van Meerwijk, M. C. (2006). Enhancing the contribution of corporate real estate to corporate strategy. Journal of Corporate Real Estate, 8(4): 188-197.

Sulaiman, N. N., Diah, M. L. M., Ramin, A., Omar, A. J., \& Ambar, A. (2015, January). Corporate real estate performance in Malaysian Public Listed companies. In Pacific-Rim Real Estate Society Conference, Kuala Lumpur, January (pp. 18-21).

van der Voordt, T. (2017). Facilities management and corporate real estate management: FM/CREM or FREM? Journal of Facilities Management, 17(3): 244-261.

van der Voordt, T. J. (2016). Adding value by health care real estate: parameters, priorities, and interventions. Journal of Corporate Real Estate, 18(2): 145-159.

Varcoe, B. (2011). The alignment of corporate real estate performance to enterprise needs Part Two: The business management view compared with CRE practice. Corporate Real Estate Journal, 1(3), 219-231.

Varcoe, B., \& O'Mara, M. (2011). Corporate real estate impact on enterprise success. Regus Global Report.

(C) 2021 by the authors. This article is an open-access article distributed under the terms and conditions of the Creative Commons Attribution (CC BY) license (http://creativecommons.org/licenses/by/4.0/). 